\title{
Stability of Levetiracetam in Extemporaneously Compounded Suspensions
}

\author{
Mary H H Ensom, Diane Decarie, and Susan Rudolph
}

\begin{abstract}
Background: Levetiracetam is widely used as adjunctive therapy in the treatment of partial-onset seizures, myoclonic seizures, primary generalized tonic-clonic seizures, and idiopathic generalized epilepsy in the community and in hospital. However, no convenient, easy-to-swallow dosage form is commercially available in Canada. Moreover, no stability data are available for this antiepileptic prepared in a vehicle combining Ora-Sweet sweetener and Ora-Plus suspending agent.
\end{abstract}

Objective: To evaluate the stability of levetiracetam suspensions in amber plastic bottles at room temperature and under refrigeration for up to 91 days.

Methods: Suspensions of levetiracetam $(50 \mathrm{mg} / \mathrm{mL})$ were prepared in a 1:1 mixture of Ora-Sweet sweetening agent and Ora-Plus suspending agent. The suspensions were transferred to $50-\mathrm{mL}$ amber plastic prescription bottles, which were stored at $25^{\circ} \mathrm{C}$ or at $4^{\circ} \mathrm{C}$. Samples were collected from each bottle at time zero and on days 7, 14, 21, 28, 35, 42, 49, $56,63,70,77,84$, and 91 . The samples were analyzed in triplicate by a validated, stability-indicating high-performance liquid chromatography method with ultraviolet detection. A suspension was considered stable if it maintained at least $90 \%$ of its initial concentration of levetiracetam. Colour, odour, taste, clarity, and $\mathrm{pH}$ were assessed to determine physical compatibility.

Results: All samples remained physically unchanged over time, and there was no significant change in $\mathrm{pH}$. The $95 \%$ confidence interval of the slope of the curve relating concentration to time, determined by linear regression, indicated that suspensions stored at $25^{\circ} \mathrm{C}$ would maintain at least $91.4 \%$ of the initial levetiracetam concentration for 91 days and that suspensions stored at $4^{\circ} \mathrm{C}$ would maintain at least $93.2 \%$ of the initial concentration for 91 days, with $95 \%$ confidence.

Conclusion: Levetiracetam suspensions prepared in Ora-Sweet/Ora-Plus vehicle and stored in plastic prescription bottles at either $25^{\circ} \mathrm{C}$ or $4^{\circ} \mathrm{C}$ can be expected to remain stable for 91 days.

Key words: levetiracetam, suspension, stability

\section{RÉSUMÉ}

Contexte : Le lévétiracétam est largement utilisé comme traitement d'appoint dans le traitement des crises partielles, des crises myocloniques, des crises tonico-cloniques généralisées primaires et de l'épilepsie généralisée idiopathique dans la communauté et dans les hôpitaux. Cependant, il n'existe aucune forme pharmaceutique pratique et facile à avaler au Canada. En outre, il n'y a aucune donnée disponible sur la stabilité de cet antiépileptique préparé dans un excipient combinant l'édulcorant Ora-Sweet et l'agent de suspension Ora-Plus.

Objectif : Évaluer la stabilité de suspensions de lévétiracétam conditionnées dans des flacons en plastique ambré et conservées à la température ambiante et au réfrigérateur pendant un maximum de 91 jours.

Méthodes : Des suspensions de lévétiracétam $(50 \mathrm{mg} / \mathrm{mL})$ ont été préparées dans un mélange 1:1 d'Ora-Sweet (édulcorant) et d'Ora-Plus (agent de suspension). Les suspensions ont été transférées dans des flacons pour médicaments d'ordonnance en plastique ambré de $50 \mathrm{~mL}$ puis entreposées à une température de $25^{\circ} \mathrm{C}$ ou de $4{ }^{\circ} \mathrm{C}$. Des échantillons ont été prélevés de chaque flacon au temps zéro puis aux jours $7,14,21,28$, 35, 42, 49, 56, 63, 70, 77, 84 et 91. Les échantillons ont été analysés en triple à l'aide d'une épreuve validée par chromatographie liquide haute performance avec détection ultraviolette mesurant la stabilité. La suspension était considérée comme stable si elle conservait au moins $90 \%$ de la concentration initiale de lévétiracétam. La compatibilité physique des suspensions de lévétiracétam a été évaluée en contrôlant tout changement dans la couleur, l'odeur, le goût, la limpidité et le $\mathrm{pH}$ des préparations.

Résultats : Aucun changement des propriétés physiques ni aucun changement significatif du $\mathrm{pH}$ des suspensions n’ont été observés dans le temps. L'intervalle de confiance à $95 \%$ de la pente de la courbe de la concentration en fonction du temps, déterminée par régression linéaire, a montré que les suspensions de lévétiracétam entreposées à $25^{\circ} \mathrm{C}$ conserveraient au moins $91,4 \%$ de la concentration initiale de lévétiracétam pendant 91 jours et que les suspensions entreposées à $4^{\circ} \mathrm{C}$ conserveraient au moins 93,2\% de la concentration initiale de lévétiracétam pendant 91 jours, avec un niveau de confiance de $95 \%$.

Conclusion : Les suspensions de lévétiracétam préparées dans un excipient composé d'Ora-Sweet et d'Ora-Plus, puis conditionnées dans des flacons pour médicaments d'ordonnance en plastique et entreposées à $25^{\circ} \mathrm{C}$ ou à $4{ }^{\circ} \mathrm{C}$ devraient demeurer stables pendant 91 jours.

Mots clés : lévétiracétam, suspension, stabilité

[Traduction par l'éditeur] 


\section{INTRODUCTION}

$\mathrm{L}$ evetiracetam is an anticonvulsant used as adjunctive therapy in the treatment of partial-onset seizures, myoclonic seizures, primary generalized tonic-clonic seizures, and idiopathic generalized epilepsy in both adults and children. ${ }^{1}$ As well, a number of non-epilepsy indications, such as Tourette syndrome, migraine, and other psychiatric and pain disorders, have been described. ${ }^{2-4}$

Levetiracetam is commonly used at the authors' institution. Unfortunately, in Canada, levetiracetam is not available in a liquid dosage form. ${ }^{5}$ A search of Embase, PubMed, and International Pharmaceutical Abstracts revealed no publications on the stability of levetiracetam in a mixture of Ora-Sweet sweetening agent and Ora-Plus suspending agent. As well, no recipes or stability information on levetiracetam suspensions was available from the Compounding Service at The Hospital for Sick Children in Toronto, Ontario, ${ }^{6}$ the nonsterile compounding service of the Children's Hospital of Eastern Ontario in Ottawa, Ontario, ${ }^{7}$ the Calgary Health Region Pharmacy Compounding Manual, ${ }^{8}$ or the Professional Compounding Centers of America. ${ }^{9}$ An informal unpublished survey of inpatient and ambulatory care pharmacists within the authors' institution and of pharmacists at other pediatric institutions in Canada pointed to levetiracetam suspension as one of the most frequently compounded formulations for which stability data are still needed.

The purpose of this study was to evaluate the stability of levetiracetam suspensions $(50 \mathrm{mg} / \mathrm{mL})$ stored in amber plastic bottles at room temperature $\left(25^{\circ} \mathrm{C}\right)$ and under refrigeration $\left(4^{\circ} \mathrm{C}\right)$ for up to 91 days.

\section{METHODS}

\section{Preparation of Levetiracetam and Set-up}

Levetiracetam suspension $(50 \mathrm{mg} / \mathrm{mL})$ was prepared by crushing commercially available 500-mg tablets (Apotex, Toronto, Ontario; lot JE3297, expiry April 2011) and resuspending the powder in a 1:1 mixture of Ora-Sweet and Ora-Plus (Paddock Laboratories Inc, Minneapolis, Minnesota; lots 8374147 and 9126395, respectively; expiry date March 2011 for both). The prepared suspension was distributed into 2 sets of three $50-\mathrm{mL}$ amber plastic prescription bottles (Richards Distribution, Richmond, British Columbia). One set of bottles was kept at room temperature $\left(25^{\circ} \mathrm{C}\right)$, and the other set was refrigerated $\left(4^{\circ} \mathrm{C}\right)$.

\section{Physical Compatibility}

The physical characteristics of the suspensions were evaluated qualitatively at the time of preparation and at weekly intervals up to 91 days. As samples were collected for analysis, the same individual (D.D.) tested all suspensions for physical properties. Each sample was visually examined for changes in colour (against a white background). The samples were also tested for changes in taste and ease of resuspension. One aliquot was collected from each bottle at each time point for determination of $\mathrm{pH}$. At the beginning of each testing session, the $\mathrm{pH}$ meter (model 8000, VWR International, Mississauga, Ontario) was calibrated using commercially available standards ( $\mathrm{pH} 7.00$ and 4.00 reference solutions, Sigma-Aldrich, Oakville, Ontario; lots $038 \mathrm{~K} 0073$ and $088 \mathrm{~K} 0735$, respectively). Immediately after the physical observations were made, a $1.5-\mathrm{mL}$ sample from each storage bottle was transferred to a $2-\mathrm{mL}$ polypropylene lowtemperature freezer vial (VWR International, Mississauga, Ontario; lot 325792596 ) and immediately stored at $-85^{\circ} \mathrm{C}$ until the time of analysis.

\section{Chemical Stability Preparation of Stocks, Standards, and Calibration Curves}

Stock suspensions of levetiracetam $50 \mathrm{mg} / \mathrm{mL}$ in a $1: 1$ mixture of Ora-Sweet and Ora-Plus were prepared from levetiracetam powder (Srini Pharmaceuticals, Hyderabad, India; lot X09146, expiry September 2010). The internal standard was lamotrigine (Sigma-Aldrich; lot 068K1097, no expiry date) diluted to a concentration of $5 \mathrm{mg} / \mathrm{mL}$ in dimethylsulphoxide (Fisher Scientific, Richmond, British Columbia; lot 963960, no expiry date). Lamotrigine was further diluted, to a concentration of $0.1 \mathrm{mg} / \mathrm{mL}$, in high-performance liquid chromatography (HPLC)-grade water (Fisher Scientific; lot 096832, no expiry date).

Standards were prepared as follows. Levetiracetam $50 \mathrm{mg} / \mathrm{mL}$ was diluted to a concentration of $10 \mathrm{mg} / \mathrm{mL}$ with HPLC-grade water. The suspension was centrifuged (AccuSpin 1R, Fisher Scientific) for $10 \mathrm{~min}$ at $2560 \mathrm{~g}$, and the supernatant was diluted in HPLC-grade water to concentrations of $0.5,1.0,2.0,3.0$, and $4.0 \mathrm{mg} / \mathrm{mL}$ for construction of the calibration curve. Standards were prepared by combining $0.5 \mathrm{~mL}$ of each levetiracetam stock suspension with $0.5 \mathrm{~mL}$ lamotrigine 0.1 $\mathrm{mg} / \mathrm{mL}$. The final concentrations of levetiracetam injected onto the chromatograph were $0.25,0.5,1.0,1.5$, and $2.0 \mathrm{mg} / \mathrm{mL}$, and the final concentration of lamotrigine in each standard was $0.05 \mathrm{mg} / \mathrm{mL}$. All standards were passed through a GHP (Gelman hydrophilic propylene) 13-mm diameter, 0.45- $\mu \mathrm{m}$ micro-filter (Waters Ltd, Mississauga, Ontario; lot 21746646) to prevent injection of impurities onto the column.

A 5-point calibration curve was prepared, with a blank (water) at the beginning of each run to prevent carryover from one run to the next. The range of the calibration curve $(0.25$ to $2.0 \mathrm{mg} / \mathrm{mL}$ ) encompassed the final diluted test concentration of levetiracetam (i.e., $1.0 \mathrm{mg} / \mathrm{mL}$ ). Each calibration curve was generated by least-squares regression of the peak area ratio of levetiracetam to lamotrigine (the internal standard) versus the concentration of each levetiracetam standard. The accuracy of the assay was calculated as the mean deviation between nominal and observed concentrations. Precision of the assay was evaluated by intraday and interday variation methods. The intraday variability was determined by running the standards' lowest 
limit of quantitation and low, medium, and high concentrations $(0.3,0.6,1.2$, and $1.8 \mathrm{mg} / \mathrm{mL}$, respectively) in quadruplicate throughout the same day. Interday variability was determined by running the same concentrations on 4 different days. Mean, standard deviation, coefficient of variation $(\mathrm{CV})$, and accuracy were calculated. The acceptable limit of the $\mathrm{CV}$ was defined a priori as less than $10 \%$, and the acceptable limit of accuracy was defined a priori as greater than $90 \%$.

\section{Preparation of Samples}

The frozen samples were thawed at room temperature. A 0.5-mL aliquot from each sample was diluted with $2.0 \mathrm{~mL}$ of HPLC-grade water in $12 \times 75 \mathrm{~mm}$ glass dilution tubes (VWR International, Edmonton, Alberta) and centrifuged for $10 \mathrm{~min}$ at $2560 \mathrm{~g}$. A $0.1-\mathrm{mL}$ aliquot of supernatant was then combined with $0.5 \mathrm{~mL}$ lamotrigine $0.1 \mathrm{mg} / \mathrm{mL}$ and $0.4 \mathrm{~mL}$ of HPLCgrade water in a glass dilution tube. The final concentration of the diluted sample was $1.0 \mathrm{mg} / \mathrm{mL}$ in a total volume of $1.0 \mathrm{~mL}$. Each sample was passed through a $0.45-\mu \mathrm{m}$ micro-filter before a 5- $\mathrm{LL}$ sample was withdrawn and injected onto the column.

\section{HPLC Instrumentation}

The HPLC instrumentation (model 2690, Waters Alliance System, Waters Ltd, Mississauga, Ontario) consisted of a delivery pump, an automatic injector system equipped with a $200-\mu \mathrm{L}$ injector, a Kinetex 2.6- $\mu \mathrm{m}$ C18 $(100 \times 4.6 \mathrm{~mm})$ silica core column (Phenomenex, Torrance, California; lot 528234-28), a KrudKatcher Ultra 0.5- $\mathrm{m}$ in-line filter (Phenomenex; lot AF0-8497-SP), and an ultraviolet detector (dual absorbance detector, model 2487, Waters Alliance System, Waters Ltd) set at $213 \mathrm{~nm}$. The mobile phase consisted of a 5:16:79 (v/v/v) mixture of acetonitrile (VWR International, Edmonton, Alberta; lot 49027, no expiry date), methanol (Fisher Scientific; lot 0869535 , no expiry date), and $0.005 \mathrm{~mol} / \mathrm{L}$ solution of potassium dihydrogen phosphate $\left(\mathrm{KH}_{2} \mathrm{PO}_{4}\right.$; Sigma-Aldrich; lot 107K0100, no expiry date) at pH 3.6. All solvents were HPLCgrade and were filtered before use. The samples were eluted at room temperature $\left(25^{\circ} \mathrm{C}\right)$, and the flow rate was set at 0.75 $\mathrm{mL} / \mathrm{min}$ to achieve timely chromatograms. The assay was developed in the authors' laboratory on the basis of previous work by others. ${ }^{10}$

\section{Degradation of Levetiracetam}

Levetiracetam $10 \mathrm{mg} / \mathrm{mL}$ was prepared in HPLC-grade water from a $50 \mathrm{mg} / \mathrm{mL}$ stock suspension (in Ora-Sweet/OraPlus). A 5-mL aliquot of this solution was boiled for $20 \mathrm{~min}$, cooled to room temperature, and diluted to $1 \mathrm{mg} / \mathrm{mL}$ with HPLC-grade water. The sample was then filtered and injected onto the column. The chromatogram obtained for the degraded sample was compared with a chromatogram obtained from the calibration curve to determine any changes in concentration, retention time, and shape of the peak.

\section{Statistical Analysis}

Mean values, standard deviations, coefficients of variation, and accuracy were calculated for samples analyzed in triplicate (experimental samples) and in quadruplicate (validation standards). The percentage of initial levetiracetam concentration remaining was calculated for each sample, and stability was defined as maintenance of at least $90 \%$ of the initial concentration. The percentage of levetiracetam remaining at 91 days was calculated from the concentration at 91 days, as determined by linear regression, and the concentration calculated at time zero, according to the following formula: concentration at 91 days :concentration at time zero $\times 100 \%$. The $95 \%$ confidence interval (CI) of the amount remaining at 91 days was calculated from the lower limit of the $95 \%$ CI of the slope of the curve relating concentration and time, determined by linear regression via computer analysis, according to the following formula: lower limit of the $95 \%$ CI of the concentration at 91 days : concentration at time zero $\times 100 \%$.

\section{RESULTS}

The regression analysis of the peak area ratio of levetiracetam to lamotrigine (the internal standard) versus the concentration of each levetiracetam standard demonstrated linearity over the range of concentrations, with coefficient of determination $\left(r^{2}\right)$ greater than $0.996(n=4)$. The intraday and interday CVs were within acceptable limits (i.e., $<10 \%$ ): $4.5 \%$ and $7.6 \%$ at $0.3 \mathrm{mg} / \mathrm{mL}, 4.8 \%$ and $7.6 \%$ at $0.6 \mathrm{mg} / \mathrm{mL}, 3.3 \%$ and $5.3 \%$ at $1.2 \mathrm{mg} / \mathrm{mL}$, and $2.7 \%$ and $2.6 \%$ at $1.8 \mathrm{mg} / \mathrm{mL}$, respectively. Intraday and interday accuracy were also within acceptable limits (i.e., $>90 \%$ ): $95.9 \% \pm 3.1 \%$ and $96.4 \% \pm 7.7 \%$ at $0.3 \mathrm{mg} / \mathrm{mL}, 94.8 \% \pm 2.8 \%$ and $98.6 \% \pm 7.6 \%$ at $0.6 \mathrm{mg} / \mathrm{mL}$, $96.1 \% \pm 3.1 \%$ and $97.7 \% \pm 5.3 \%$ at $1.2 \mathrm{mg} / \mathrm{mL}$, and $95.8 \% \pm$ $1.3 \%$ and $95.8 \% \pm 2.6 \%$ at $1.8 \mathrm{mg} / \mathrm{mL}$, respectively.

Figure 1 depicts chromatograms from samples collected on day 0 (top) and day 91 (bottom). The retention times were $2.7 \mathrm{~min}$ for levetiracetam and $1.4 \mathrm{~min}$ for lamotrigine. No degradation products were observed in any samples during the stability study. When levetiracetam was subjected to degradation, the chromatogram showed non-interfering degradation peaks at 1.2 and $2.0 \mathrm{~min}$ (Figure 1, middle). No other interfering peaks were observed. Thus, the HPLC method was deemed capable of indicating stability.

There were no notable changes in $\mathrm{pH}$, colour, or taste over the study period. The suspensions appeared to maintain constant viscosity and were easily resuspended throughout the study period. The mean $\mathrm{pH}$ values ( \pm standard deviation) were $4.25 \pm 0.08$ for levetiracetam stored at $25^{\circ} \mathrm{C}$ and $4.34 \pm 0.09$ for levetiracetam stored at $4^{\circ} \mathrm{C}$.

The HPLC analysis showed that all levetiracetam suspensions stored in amber plastic bottles at $25^{\circ} \mathrm{C}$ or $4^{\circ} \mathrm{C}$ maintained at least $90 \%$ of their initial levetiracetam concentrations for 91 days (Table 1). Specifically, the $95 \%$ confidence interval of the 
Table 1. Percentage of Initial Concentration of Levetiracetam Remaining after Storage at $25^{\circ} \mathrm{C}$ and $4^{\circ} \mathrm{C}$

\begin{tabular}{|c|c|c|}
\hline \multirow[b]{2}{*}{ Study Day } & \multicolumn{2}{|c|}{$\begin{array}{l}\text { Storage Temperature; \% Remaining* } \\
\text { (Mean } \pm \text { SD) }\end{array}$} \\
\hline & $25^{\circ} \mathrm{C}$ & $4^{\circ} \mathrm{C}$ \\
\hline Initial concentration $(\mathrm{mg} / \mathrm{mL}) \dagger$ & $1.00 \pm 0.04$ & $1.02 \pm 0.03$ \\
\hline 7 & $95.4 \pm 3.5$ & $98.0 \pm 6.7$ \\
\hline 14 & $95.3 \pm 2.7$ & $100.1 \pm 2.0$ \\
\hline 21 & $101.9 \pm 2.0$ & $95.4 \pm 6.5$ \\
\hline 28 & $101.6 \pm 5.3$ & $101.8 \pm 4.2$ \\
\hline 35 & $102.9 \pm 7.2$ & $97.7 \pm 7.8$ \\
\hline 42 & $102.8 \pm 3.8$ & $97.4 \pm 1.9$ \\
\hline 49 & $104.9 \pm 1.1$ & $97.9 \pm 6.1$ \\
\hline 56 & $100.5 \pm 8.4$ & $97.1 \pm 2.4$ \\
\hline 63 & $100.6 \pm 6.7$ & $96.2 \pm 3.0$ \\
\hline 70 & $95.4 \pm 1.7$ & $96.6 \pm 2.3$ \\
\hline 77 & $94.6 \pm 3.1$ & $95.1 \pm 3.6$ \\
\hline 84 & $95.0 \pm 3.8$ & $99.3 \pm 1.2$ \\
\hline 91 & $100.0 \pm 6.5$ & $94.8 \pm 9.2$ \\
\hline $\begin{array}{l}\text { \% remaining on day } 91 \text { by linear } \\
\text { regression‡ }\end{array}$ & $98.1 \%$ & $96.6 \%$ \\
\hline $\begin{array}{l}\text { Lower limit of } 95 \% \mathrm{Cl} \text { for } \\
\% \text { remaining } \S\end{array}$ & $91.4 \%$ & $93.2 \%$ \\
\hline \multicolumn{3}{|c|}{$\begin{array}{l}\mathrm{Cl}=\text { confidence interval, } \mathrm{SD}=\text { standard deviation. } \\
\text { * Percent of initial concentration (except where indicated otherwise) is reported as mean } \\
\pm \mathrm{SD} \text { of } 3 \text { samples. } \\
+ \text { Nominal concentration was } 1.0 \mathrm{mg} / \mathrm{mL} \text {. } \\
\text { †Calculated from concentration on day } 91 \text { as determined by linear regression and } \\
\text { concentration at time zero, according to the following formula: concentration at day } 91 \\
\div \text { concentration at time zero x } 100 \text {. } \\
\S \mathrm{Calculated} \text { from lower limit of } 95 \% \mathrm{Cl} \text { of the slope of the curve relating concentration } \\
\text { to time, determined by linear regression, according to the following formula: lower limit } \\
\text { of } 95 \% \mathrm{Cl} \text { of concentration at day } 91 \div \text { concentration at time zero x } 100 \text {. }\end{array}$} \\
\hline
\end{tabular}

slope of the curve relating concentration to time, determined by linear regression, indicated that levetiracetam suspensions stored at $25^{\circ} \mathrm{C}$ would maintain at least $91.4 \%$ of the initial levetiracetam concentration for 91 days and that suspensions stored at $4^{\circ} \mathrm{C}$ would maintain at least $93.2 \%$ of the initial concentration for 91 days, with $95 \%$ confidence.

\section{DISCUSSION}

The lack of a commercially available liquid formulation of levetiracetam poses problems for children and adults who are unable to swallow solids. Until the time of this study, levetiracetam oral suspension (in Ora-Sweet and Ora-Plus) was prepared on an "as needed" basis by the pharmacy staff of the authors' hospital and was given an arbitrary short expiration date of 14 days. To the authors' knowledge, there are no published stability studies for levetiracetam suspensions prepared in equal volumes of Ora-Sweet and Ora-Plus.

In the serial analysis of samples reported here, no notable changes in colour, taste, $\mathrm{pH}$, or ease of resuspension were observed for levetiracetam suspensions stored in amber plastic bottles at $25^{\circ} \mathrm{C}$ or $4^{\circ} \mathrm{C}$ throughout the 91 -day period. Although the measures of physical characteristics (aside from $\mathrm{pH}$ ) were qualitative, all observations were documented by the same individual throughout the study period, which eliminated interobserver bias.

According to the HPLC and statistical analyses, levetiracetam suspensions stored at $25^{\circ} \mathrm{C}$ can be expected to maintain at least $91.4 \%$ of the initial levetiracetam concentration for 91 days, and suspensions stored at $4^{\circ} \mathrm{C}$ should maintain at least $93.2 \%$ of the initial concentration for 91 days, with $95 \%$ confidence.

One limitation of the study relates to the freezing of samples at $-85^{\circ} \mathrm{C}$ until the time of batch analysis (up to 6 months). It is generally assumed that during storage at $-70^{\circ} \mathrm{C}$ or colder, drug degradation is limited, provided the duration of storage is reasonable; furthermore, freeze-drying is limited if storage containers are sealed. Considering previously published data $^{11}$ and the fact that, in the current study, the observed concentration of $1 \mathrm{mg} / \mathrm{mL}$ on day 0 (and day 91) was as expected (with no degradation products observed in any samples 


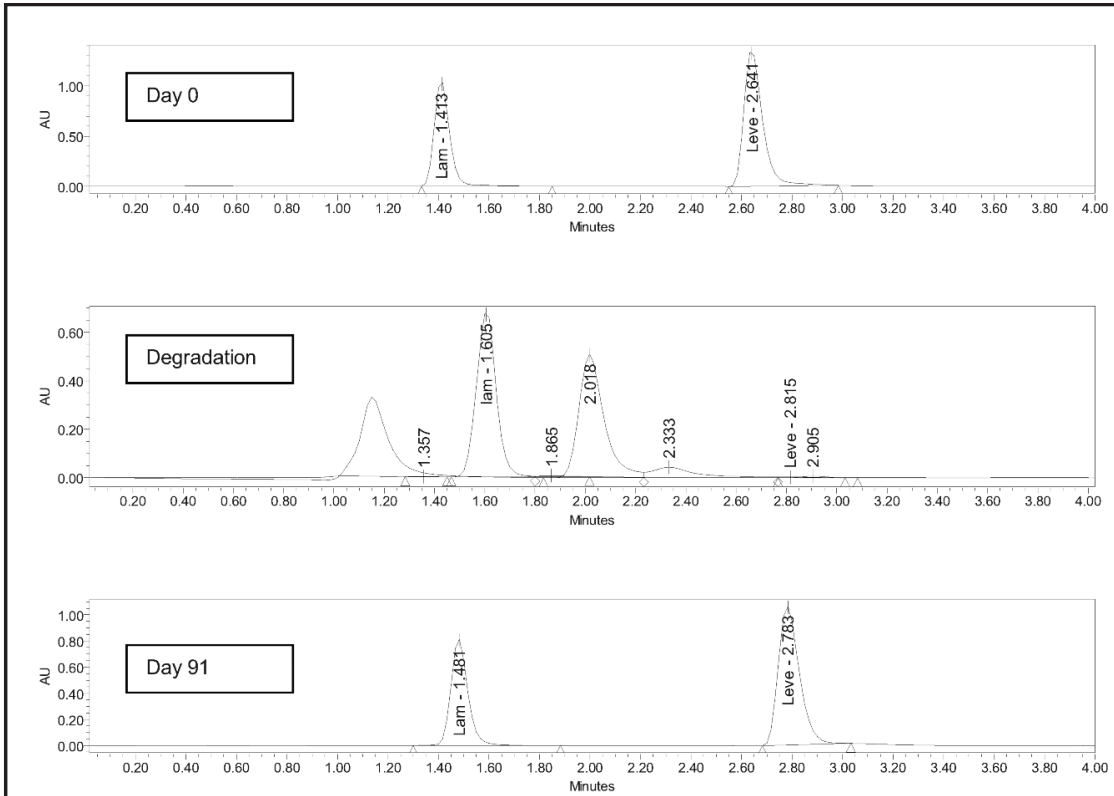

Figure 1. Top: Sample obtained on day 0, with internal standard (lamotrigine [Lam]) peak at 1.4 min and levetiracetam (Leve) peak at 2.6 min. Middle: Sample from heat-degraded preparation, showing disappearance of the levetiracetam peak and non-interfering degradation peaks at 1.2 and 2.0 min. Bottom: Sample obtained on day 91, with no interfering peaks. AU = absorbance units.

during the stability analysis), it was assumed that no degradation or volume losses occurred due to freeze-drying during storage at $-85^{\circ} \mathrm{C}$. It was also assumed that errors due to serial analysis would be greater than any errors associated with batch analysis.

\section{CONCLUSIONS}

According to serial qualitative assessment of physical properties, $\mathrm{pH}$, and HPLC analyses, levetiracetam suspensions $(50 \mathrm{mg} / \mathrm{mL})$ prepared in a mixture of Ora-Sweet and Ora-Plus and stored in plastic prescription bottles at either $25^{\circ} \mathrm{C}$ or $4^{\circ} \mathrm{C}$ are expected to be stable for 91 days.

\section{References}

1. Levetiracetam drug information provided by Lexi-Comp. In: The Merck manual for healthcare professionals. Whitehouse Station (NJ): Merck \& Co, Inc; 2010 Jan [cited 2010 Aug 13]. Available from: www.merck.com/ mmpe/lexicomp/levetiracetam.html

2. Perry MS, Benatar M. Efficacy and tolerability of levetiracetam in children younger than 4 years: a retrospective review. Epilepsia 2007;48(6):11231127.

3. Ettinger AB, Argoff CE. Use of antiepileptic drugs for nonepileptic conditions: psychiatric disorders and chronic pain. Neurotherapeutics 2007; 4(1):75-83.

4. Awaad Y, Michon AM, Minarik S. Use of levetiracetam to treat tics in children and adolescents with Tourette syndrome. Mov Disord 2005; 20(6):714-718.

5. Levetiracetam. In: Health Canada drug product database. Ottawa (ON): Health Canada [cited 2010 Aug 13]. Available from: http://webprod. hc-sc.gc.ca/dpd-bdpp/index-eng.jsp

6. Compounding service. Toronto (ON): The Hospital for Sick Children; [cited 2010 Aug 13]. Available from: www.sickkids.ca/Pharmacy/ Compounding-Service/index.html

7. For pharmacists [information about nonsterile compounding]. Ottawa (ON): Children's Hospital of Eastern Ontario [cited 2010 Aug 13]. Available from: www.cheo.on.ca/en/healthcareprofessionalsforpharmacists
8. Calgary Health Region pharmacy compounding manual. 5th ed. Calgary (AB): Calgary Health Region Pharmacy; 2010.

9. Professional Compounding Centers of America [homepage on Internet]. Houston (TX): Professional Compounding Centers of America [cited 2010 Aug 13]. Available from: www.pccarx.com/

10. Matar KM, Nicholls PJ, Bawazir SA, al-Hassan MI, Tekle A. A rapid liquid chromatographic method for the determination of lamotrigine in plasma. J Pharm Biomed Anal 1998;17(3):525-531.

11. Matar KM. Quantification of levetiracetam in human plasma by liquid chromatography - tandem mass spectrometry: application to therapeutic drug monitoring. J Pharm Biomed Anal 2008;48(3):822-828.

Mary H H Ensom, PharmD, FASHP, FCCP, FCSHP, FCAHS, is Professor and Director, Doctor of Pharmacy Program, Faculty of Pharmaceutical Sciences, and Distinguished University Scholar, The University of British Columbia, and Clinical Pharmacy Specialist, Department of Pharmacy, Children's and Women's Health Centre of British Columbia, Vancouver, British Columbia. She is also the Editor of CJHP.

Diane Decarie, BSc, is Research Consultant, Department of Pharmacy, Children's and Women's Health Centre of British Columbia, Vancouver, British Columbia.

Susan Rudolph, BSC(Pharm), is Pharmacy Coordinator, Pharmacy Department, Children's and Women's Health Centre of British Columbia, Vancouver, British Columbia.

\section{Address correspondence to:}

Dr Mary H H Ensom

Department of Pharmacy (OB7)

Children's and Women's Health Centre of British Columbia

4500 Oak Street

Vancouver BC V6B 6E4

e-mail: ensom@mail.ubc.ca

\section{Acknowledgments}

This study was supported by a grant from the Medbuy Pharmacy Research, Education, and Development Fund. 